\title{
GAMBARAN SPIRITUALITAS REMAJA YANG TINGGAL DI SEKITAR EKS-LOKALISASI
}

\author{
Ah. Yusuf, Rr Dian Tristiana, Nina Agustina \\ Fakultas Keperawatan Universitas Airlangga, Surabaya, Indonesia \\ E-mail: ah-yusuf@fkp.unair.ac.id
}

\begin{abstract}
Spirituality is one of the most influential dimensions in adolescent development. Adolescent with good spiritual sees life with optimism, clean mind and soul. Environment will affect the spiritual development of adolescents. This research aimed to understanding the adolescent spirituality living around ex-localization. This research used qualitative research design of phenomenology with in-depth interview with semi structured interview and observation. Participants were junior high school teenagers, Moslems living around exlocalization, Kota Surabaya, choose by purpossive sampling. The data analysis in this study using thematic analysis with nine steps Collaizzi. result of this research got 18 theme that is adolescent perception, adolescent behavior, adolescent relationship with parents, interaction of adolescent with society, interaction of adolescent with opposite sex, adolescent knowledge, adolescent relationship with self, autonomy, feeling during worship, SWT, the purpose of human creation, religious analysis, Allah's incomprehension, the timeliness of worship, obstacles, life goals, hopes, spiritual experiences, ways of dealing with problems, lifestyles, self-image. Adolescents who live in an ex-localization will interact with peers and the surrounding community in the neighborhood. These reciprocal relationships affect the spiritual values in teenagers. The existence of the control of parents can control the interaction process that occurs between adolescents with the surrounding community who live in ex-localization so that formed the spiritual character of adolescents.

Keyword: spirituality, adolescence, ex-localization
\end{abstract}

Abstrak: Spiritualitas merupakan salah satu dimensi yang berpengaruh dalam perkembangan remaja. Remaja dengan spiritual yang baik akan memandang kehidupan dengan optimis, jiwa dan pikiran bersih. Lingkungan akan mempengaruhi perkembangan spiritual remaja. Tujuan penelitian ini adalah untuk mengetahui gambaran spiritualitas remaja yang tinggal disekitar eks-lokalisasi. Penelitian ini menggunakan desain penelitian kualitatif fenomenologi dengan metode indepth interview dengan wawancara semi terstruktur dan observasi. Partisipan adalah remaja Sekolah Menengah Pertama, beragama Islam yang tinggal di sekitar eks-lokalisasi, Kota Surabaya, dipilih secara purposif sampling. Analisis data dalam penelitian ini menggunakan teknik sembilan langkah Collaizzi. hasil penelitian ini didapatkan 18 tema yaitu persepsi remaja, perilaku remaja, hubungan remaja dengan orang tua, interaksi remaja dengan masyarakat sekitar, interaksi remaja dengan lawan jenis, pengetahuan remaja, hubungan remaja dengan diri sendiri, otonomi, perasaan saat beribadah, identifikasi Allah SWT, tujuan penciptaan manusia, analisis agama, ketidakyakinan Allah SWT, ketepatan waktu beribadah, hambatan, tujuan hidup, harapan, pengalaman spiritual, cara menghadapi masalah, gaya hidup, gambaran diri. Remaja yang tinggal di eks-lokalisasi akan menjalin interaksi dengan teman sebaya dan masyarakat sekitar di lingkungan tempat tinggal. Hubungan timbal balik tersebut mempengaruhi niali-nilai spiritual dalam diri remaja. Adanya kontrol dari orang tua mampu 
mengendalikan proses interaksi yang terjadi antara remaja dengan masyarakat sekitar yang tinggal di eks-lokalisasi sehingga terbentuklah karakter spiritual remaja.

\section{Kata kunci : spiritualitas, remaja, eks-lokalisasi}

\section{PENDAHULUAN}

Remaja merupakan masa transisi dari masa anak-anak menuju masa dewasa yang ditandai dengan berbagai perubahan. Miller (1993) dalam Baihaqi et all (2010) mengatakan bahwa masa remaja "may be seen in the descriptive label given in this periode of life as a "storm and stress" period". Pada masa remaja, seseorang mengalami beberapa perubahan, baik secara fisik maupun secara psikis yaitu perubahan dalam proses biologis, psikologis, sosiologis dan spiritual. Perubahan yang terjadi akan mendorong remaja dalam melakukan perilaku yang positif maupun negatif yaitu kecenderungan untuk melakukan kenakalan remaja Mufna, Hardjajani (2004).

Fenomena kenakalan remaja maupun kecenderungannya mayoritas dilakukan oleh remaja di bawah usia 21 tahun (Kartono, 2006). Penelitian yang dilakukan Kemenkes 2009 menunjukkan bahwa sebanyak $35.9 \%$ remaja di Surabaya sudah pernah melakukan hubungan seksual sebelum menikah. Bahkan, 6,9\% responden telah melakukan hubungan seksual pranikah. Kemenkes 2016 melaporkan sebanyak 82,8\% jumlah HIV pada usia 11-29 tahun ditularkan melalui hubungan seksual, baik lesbian, homoseksual ataupun hubungan normal. Rentang usia remaja antara 13-18 tahun yang pernah melakukan hubungan seks di luar nikah tercatat di Surabaya mencapai $54 \%$, di Medan 52\%, Bandung 47\%, dan Jogjakarta 37\% (Kemenpora 2009; Kementerian Kesehatan RI 2016; Sulistiawan et al. 2010).
Data yang bersumber dari Badan Pusat Statistik bulan Februari 2016 jumlah penduduk remaja berusia 15-24 tahun di Indonesia sebanyak 43.668.757 dengan pravalensi sekitar $50 \%$ sudah memiliki tanggung jawab sebagai angkatan kerja. Sedangkan survei yang dilakukan Badan Pusat Statistika Kota Surabaya pada tahun 2014 penduduk remaja berusia 15-24 tahun berjumlah 186.672 jiwa (Badan Pusat Statistik Republik Indonesia 2013; BPS 2014). Surabaya sendiri sebagai kota metropolitan kedua setelah Jakarta juga memiliki jumlah kenakalan remaja yang tinggi. Kecamatan Sawahan merupakan wilayah yang mencakup salah satunya adalah eks lokalisasi, artinya fenomena perilaku seksual yang terjadi di wilayah eks lokalisasi berdampak buruk terhadap masyarkat sekitarnya termasuk remaja dan dapat berujung pada penyakit HIV (BNN 2015; Indonesia 2012).

Setyaningsih (2006) mendefinisikan kecenderungan kenakalan remaja sebagai perilaku remaja yang mengarah pada perilaku asosial akibat ketidakmampuan remaja untuk menjalin hubungan baik dengan lingkungan dan menjalankan norma masyarakat. Kecenderungan kenakalan remaja dipengaruhi oleh faktor internal dan eksternal. Salah satu faktor internal penyebab kenakalan remaja diduga terkait dengan ketidakmampuan remaja untuk mengontrol tingkah lakunya dalam menghadapi berbagai pola perubahan kehidupan yang bersamaan dengan perubahan fisik, psikis, sosial cukup membingungkan (Hurlock 2004). 
Erikson dalam Baihaqi dkk (2010) mengatakan bahwa identitas remaja merupakan konsep integrasi antara individu itu sendiri dengan lingkunganya. Dapat ditarik kesimpulan bahwa selain lingkungan, ada sesuatu atau pedoman dalam diri individu yang mampu membentuk diri remaja. Sedangkan pendapat Wahl dkk (2008) dalam Alexis \& Gowri (2014) menjelaskan tingkatan dalam diri invididu yang mampu mengatur dan memberikan kenyamanan serta memotivasi diri untuk melakukan sesuatu sesuai dengan kaidahnya disebut dengan spiritual (Baihaqi et all 2010); Alexis \& Gowri 2014).

Remaja yang memiliki spiritual yang baik akan memandang kehidupan dengan optimis, jiwa dan pikiran bersih serta tidak menjatuhkan diri kepada kerusakan yang terjadi lingkungan tempat tinggal. Dari permasalahan tersebut peneliti timbul pertanyaan tentang bagaimana spiritual pada remaja yang tinggal di eks lokalisasi, aktifitas spiritual dalam kehidupan sehari-hari sesuai dengan fenomena perilaku seksual yang terjadi di wilayah eks lokalisasi, Kota Surabaya. Berdasarkan latar belakang tersebut peneliti ingin mengetahui bagaimana gambaran spiritualitas remaja yang tinggal di sekitar eks lokalisasi, Kota Surabaya.

\section{METODE}

Desain penelitian ini adalah kualititatif fenomenologi. Desain ini dipilih peneliti karena peneliti ingin mendapatkan gambaran pengalaman partisipan terkait spiritualitas partisipan. Partisipan dipilih secara purposif dengan kriteria inklusi yaitu remaja (usia 14-16 tahun), tinggal di sekitar eks-lokalisasi, kota Surabaya. Pengumpulan data dilakukan dengan wawancara semi terstruktur, dengan alat bantu; pedoman wawancara, catatan lapangan, dan recorder berupa voice recorder. Peneliti memperoleh data remaja dari kelurahan setempat dan kemudian mendatangi remaja dan memberikan inform consent pada orangtua remaja setelah memberikan penjelasan penelitian terlebih dahulu pada orangtua remaja dan remaja. Setiap sesi wawancara dilakukan selama 30-45 menit selama 2-3 kali pertemuan. Analisis data dilakukan dengan metode Collaizi. Analisis data dilakukan bersamaan dengan proses pengumpulan data. Saturasi data didapatkan pada partisipan ke delapan. Analisis data denngan menggunakan metode Collaizi dilakukan dengan membaca kembali transkrip hasil wawancara dan mengutip pernyataanpernyataan yang bermakna, Menguraikan arti yang ada dalam pernyataanpernyataan signifikan, Menguraikan arti yang ada dalam pernyataan-pernyataan signifikan, Mengorganisir kumpulankumpulan makna yang terumuskan ke dalam kelompok tema, Menuliskan deskripsi yang lengkap, Menemui partisipan untuk melakukan validasi deskripsi hasil analisis, Menggabungkan data hasil validasi ke dalam deskripsi hasil analisis.

\section{Keabsahan Data}

Peneliti melakukan validasi transkrip verbatim kepada partisipan. Peneliti juga melakukan triangulasi metode pengambilan data yaitu wawancara dan observasi serta terakhir adalah validasi kembali ke partisipan. Untuk menjamin kualitas data, peneliti juga melakukan prinsip konfirmabilitas yaitu melakukan konsultasi ke ahli yaitu supervisor penelitian yang sudah ahli dalam bidang spiritualitas.

\section{Etik Penelitian}


Penelitian ini telah mendapat persetujuan dari Komisi Etik Penelitian Kesehatan Fakultas Keperawatan Universitas Airlangga dengan nomor sertifikat laik etik 375-KEPK tanggal 12 Juni 2017.

\section{HASIL}

Mayoritas partisipan berusia 14 tahun, 4 orang pria dan 4 wanita, jarak tempat tinggal dengan eks-lokalisasi antara $50-100$ meter, lama tinggal di wilayah tersebut antara 5 sampai 15 tahun. Secara lengkap seperti pada tabel 1 .

Penelitian ini menghasilkan 18 (delapan belas) tema yang dijabarkan sesuai tujuan penelitian.

Tabel 1 Karakteristik Partisipan

\begin{tabular}{cccccc}
\hline No & Inisial & $\begin{array}{c}\text { Jenis } \\
\text { Kelamin }\end{array}$ & $\begin{array}{c}\text { Usia } \\
\text { (tahun) }\end{array}$ & $\begin{array}{c}\text { Lama Tinggal } \\
\text { (tahun) }\end{array}$ & $\begin{array}{c}\text { Jarak ke eks- } \\
\text { lokalisasi (meter) }\end{array}$ \\
\hline $\mathbf{1}$ & $\mathrm{P} 1$ & $\mathrm{~L}$ & 14 & 14 & 100 \\
\hline $\mathbf{2}$ & $\mathrm{P} 2$ & $\mathrm{p}$ & 14 & 7 & 50 \\
\hline $\mathbf{3}$ & $\mathrm{P} 3$ & $\mathrm{p}$ & 14 & 14 & 50 \\
\hline $\mathbf{4}$ & $\mathrm{P} 4$ & $\mathrm{p}$ & 16 & 16 & 50 \\
\hline $\mathbf{5}$ & $\mathrm{P} 5$ & $\mathrm{~L}$ & 15 & 15 & 50 \\
\hline $\mathbf{6}$ & $\mathrm{P} 6$ & $\mathrm{~L}$ & 14 & 14 & 100 \\
\hline $\mathbf{7}$ & $\mathrm{P} 7$ & $\mathrm{~L}$ & 14 & 5 & 80 \\
\hline $\mathbf{8}$ & $\mathrm{P} 8$ & $\mathrm{P}$ & 15 & 15 & 75 \\
\hline
\end{tabular}

\section{PEMBAHASAN}

\section{Persepsi Remaja terhadap teman} sebaya.

Persepsi remaja terhadap teman sebaya yang tinggal di sekitar ekslokalisasi adalah adanya kenakalan remaja. Kenakalan pelajar atau remaja adalah hal yang dilakukan pelajar sebagai individu dan tidak sesuai dengan norma hidup yang belaku dalam masyarakat. Remaja yang tinggal di sekitar ekslokalisasi ditemukan tiga bentuk kenakalan remaja yaitu merokok, minumminuman dan ugal-ugalan (suka ngebut, berbicara semaunya, nada keras, arogan). Dua partisipan memandang bentuk kenakalan remaja yang dilakukan adalah merokok. Berdasarkan catatan lapangan diketahui bahwa kegiatan merokok tersebut tidak hanya dilakukan oleh anak SMP bahkan SD.

Penelitian Sulistiowati 2015 menjelaskan pengaruh interaksi yang terus-menerus dengan teman sepermainan akan memberikan pengaruh kuat berupa tuntutan konformitas. Konformitas merupakan tekanan atau tuntutan untuk mengikuti teman-teman sebayanya dan ini dapat bersifat positif maupun negatif (Papali, D. E \& Fredlman 2009). Sehingga, efek yang diberikan teman sebaya yang berada di lingkungan ekslokalisasi tersebut memberikan pengaruh besar terhadap remaja di sekitarnya.

\section{Perilaku remaja}

Perilaku remaja dengan teman sebaya yang tinggal di sekitar eks- 
lokalisasi terdapat perilaku yang positif dan negatif. Perilaku negatif meliputi kematangan psikis, emosional dan merusak lingkungan. Perilaku manusia dibangun dari kepekaan sosial, kelangsungan perilaku, orientasi pada tugas, usaha dan perjuangan.

Teori psikologi lingkungan menjelaskan bahwa perilaku manusia dapat merubah lingkungannya dan lingkungan juga dapat mengundang serta mendatangkan perilaku (Nuqul 2015). Berdasarkan catatan lapangan, partisipan yang bersekolah di lingkungan sekolah full day school tidak memiliki waktu untuk melakukan perilaku diluar sekolah bahkan di lingkungn rumah tak mampu berinteraksi dengan sebaya. Kesimpulan yang dapat diambil bahwa lingkungan eks-lokalisasi pada remaja dengan jam sekolah full day maupun remaja yang tidak melakukan interaksi dengan teman sebaya di lingkungan rumah tidak memberikan dampak perilaku negatif.

\section{Pengetahuan remaja tentang lingkungan tempat tinggal}

Hubungan remaja dengan lingkungan digambarkan melalui pengetahuan remaja tentang lingkungan itu sendiri. 2 dari 8 partisipan dalam penelitian ini belum mengetahui sejarah lingkungan eks-lokalisasi. Tiga partisipan yang mengetahui sejarah lengkap wilayah tempat tinggal mereka dahulunya merupakan eks-lokalisasi. Tiga partisipan lainnya menjelaskan wilayah tempat tinggal sesuai dengan keadaan lapangan yang mereka amati sehari-hari yaitu banyaknya lalu-lalang waria di sekitar tempat tinggal.

Penelitian Amaliyasari dan Nunik (2008) informasi tentang seksual responden berhubungan dengan perilaku seksual responden. Dalam penelitian ini menyimpulkan pengetahuan remaja tentang lingkungan eks-lokalisasi mempengaruhi sikap remaja dalam berinteraksi dengan masyarakat di sekitar lingkungan tempat tinggal.

\section{Hubungan}

Hubungan merupakan proses dalam kehidupan sosial. Dalam penelitian ini, tema hubungan diperoleh empat subtema yaitu interaksi remaja dengan masyarkat sekitar, interaksi remaja dengan lawan jenis, hubungan remaja dengan orangtua, hubungan remaja dengan diri sendiri.

Hubungan tersebut dibentuk dan dipengaruhi oleh lingkungan. Interaksi dengan lawan jenis terjadi secara langsung maupun tidak langsung. Interaksi langsung dilakukan ketika malam minggu sedangkan interaksi tidak langsung dilakukan setiap hari melalui telepon seluler.

Kualitas religius masyarakat Indonesia yang baik akan memberi kontribusi yang positif bagi bertumbuhnya nilai-nilai moral, etik dan spiritual yang diyakini banyak kalangan dan menjadi penangkal untuk melakukan aktivitas seksual (Pradisukmawati and Darminto 2014). Ditarik kesimpulan bahwa nilai spiritual yang baik dapat mengurangi hubungan dengan lawan jenis terutama pada usia remaja yang memiliki nilai-nilai moral yang mesti dianutnya.

Hubungan remaja dengan orang tua dipengaruhi oleh perang orang tua dalam perkembangan religius dan spiritual remaja. Orang tua merupakan kunci bagi segala kegiatan agama, kepercayaan dan praktik dalam kegiatan spiritual. Orang tua dianggap memberi landasan bagi pengembangan keyakinan dan praktik keagamaan kaum muda. Disamping itu, adanya dorongan keluarga dapat meningkatkan perkembangan religius dan spiritual pada anak-anak 
melalui proses pengajaran formal, diskusi orang tua, pemodelan peran, dan coparticipation dalam doa dan ritual lainnya. Kualitas hubungan orang tua dan remaja adalah kunci proses sosialisasi keagamaan (King and Roeser 2008).

\section{Otonomi}

Otonomi dalam penelitian ini digambarkan melalui dua kategori yaitu pengambilan keputusan oleh diri sendiri dan orang tua. Remaja masih dalam tanggung jawab orang tua, ia belum mampu menafkahi diri sendiri sehingga dalam pengambilan keputusan seharusnya juga ditentukan oleh orang tua.

Dik (2009) dalam penelitiannya menjelaskan adanya mekanisme lain dimana spiritualitas dan agama seseorang dapat mempengaruhi pengambilan keputusan. Otonomi menuntut bahwa kita sendiri menentukan siapakah kita ini dan bersedia untuk bertanggung jawab atas pilihan itu (Hacho 2014).

Dalam penelitian satu partisipan menjelaskan bahwa pengambilan keputusan terkadang ia lakukan sendiri dengan menghiraukan keputusan yang diberikan orang. Partisipan delapan memaparkan hal yang berbeda, ia menyakini tetap mengikuti keputusan orang tua dengan berbagai keadaan serta sebab-akibat yang terjadi.

\section{Perasaan saat beribadah}

Perasaan adalah suatu keadaan dalam kesadaran manusia yang karena pengaruh pengetahuannya dinilai sebagai keadaan positif dan negatif. Tema perasaan saat beribadah dibagi menjadi dua sub tema yaitu adaptif dan maladaptif. Perasaan adaptif digambarkan melalui dua kategori tenang dan perasaan memiliki. Sub tema maladaptif digambarkan melalui kategori biasa saja.

\section{Identifikasi Tuhan}

Identifikasi Tuhan artinya penetapan identitas secara khusus oleh individu (Chaplin 2011; Yusuf dkk 2017). Dalam penelitian ini, identifikasi Tuhan Allah SWT digambarkan melalui dua kategori yaitu Maha Esa dan Maha Pencipta. Satu partisipan mengidentifikasikan Allah sebagai Tuhan yang Maha Esa hal tersebut sesuai dengan pedoman ajaran islam yang termaktub dalam Kitab Suci Al-Qur'an. 'Katakanlah (Muhammad), "Dialah Allah Yang Maha Esa", (Allah) tidak beranak dan tidak pula diperanakkan"," (QS. Al-Ikhlas : 1\&3).

\section{Tujuan Penciptaan Manusia}

Manusia dapat disebut juga spiritual. Spiritual didefinisikan menurut bahasa adalah satu zat atau makhluk immaterial, biasanya bersifat ketuhanan menurut aslinya, yang diberi sifat dari banyak ciri karakteristik manusia. Manusia sebagai makhluk spiritual akan senantiasa berpikir tentang apa dan mengapa ia diciptakan.

$\begin{array}{rrr}\text { Kitab } & \text { Suci } & \text { Al-Quran } \\ \text { menyebutkan } & \text { "Dan } & \text { tidaklah Aku }\end{array}$ menciptakan Jin dan Manusia kecuali hanya untuk beribadah kepada-Ku" (QS Adzariyat : 54). Allah SWT sudah menyebutkan secara pasti bahwa pada dasarnya tujuan penciptaan manusia adalah untuk beribadah kepada-Nya.

Analisis Agama

Tema analisis agama dapat ditentukan melalui pandangan terhadap agama yang sama yaitu agama islam secara subjektif. Subtema subjektifitas remaja terhadap analisis agama diperoleh empat kategori yaitu voluntaristik (menekan kemauan), intelektualistik (menegaskan kepercayaan), afektivistik (menyangkut perasaan), dan historistik (menggambarkan pengalaman). Penelitian yang dilakukan David ett all (2000) menyatakan adanya keterkaitan erat 
antara agama dengan spiritualitas yang tinggi. David juga menjelaskan bahwa spiritualitas merupakan bagian dari kehidupan remaja.

Berdasarkan catatan lapangan diketahui bahwa partisipan menganalisis agama sesuai dengan pengetahuan yang dimiliki. Kategori intelektualitas, partisipan menegaskan besarnya kepercayaan yang dimiliki sesuai dengan ilmu-ilmu tentang agama yang dipelajari sejak kecil. Pada kategori historitik, partisipan memiliki pengetahuan tentang agama berasumber dari pengalamanpengalaman yang dimiliki.

\section{Keyakinan terhadap Tuhan}

Tema keyakinan terhadap Allah SWT digambarkan melalui dua subtema yaitu menjalankan ritual dan tidak menjalankan. Sub tema menjalankan ritual dijelaskan melalui tiga kategori shalat, ngaji, puasa.

Hal-hal yang menjadi pilar Islam terjewantah dalam lima perkara atau disebut juga rukun Islam. 1)Mengucapkan dua kalimat syahadat, 2)Mendirikan shalat, 3)Menjalankan puasa Ramadhan, 4)Menunaikan zakat, dan 5)Pergi haji ke Baitullah bagi yang mampu. Hasil yang dapat disimpulkan dalam penelitian bahwa kegiatan ritual agama islam seperti shalat, ngaji dan puasa dapat menggambarkan spiritual individu.

\section{Usaha yang dilakukan}

Dalam menjalankan ibadah individu tidak boleh melanggar dalam tatanan aturan termasuk waktu. Waktu beribadah agama Islam dalam sehari dibagi menjadi lima. Setiap waktu beribadah baik ibadah wajib seperti shalat dan puasa di bulan Ramadhan memiliki batasan-batasan yang telah diatur. Pada penelitian ini, diketahui bahwa terdapat satu partisipan yang menjalankan ibadah sesuai waktunya. Usaha tersebut dilakukan dengan memasang alarm ketika akan bangun subuh dan sesegara mungkin ke masjid ketika adzan berkumandang ataupun ketika waktu shalat telah tiba.

\section{Hambatan beribadah}

Hambatan dalam melakukan kegiatan ibadah dalam penelitian bukan merupakan hambatan yang serius. Hambatan terjadi diakibatkan faktor yang berasal dari diri sendiri dan lingkungan. Pada diri sendiri hambatan yang terjadi karena malas dan kesiangan. Faktor lingkungan terjadi karena perubahan jadwal dan kelelahan. Faktor-faktor tersebut seharusnya dapat diantisipasi dengan keinginan yang kuat dari individu. Peneliti menyakini bahwa partisipan memang tidak memiliki keinginan untuk beribadah dengan sungguh-sungguh, terlihat ketika diajukan pertanyaan berbagai alasan diajukan partisipan.

\section{Tujuan Hidup}

Perasaan mengetahui makna hidup, yang kadang diidentifikasikan dengan perasaan dekat dengan Tuhan, merasakan hidup sebagai suatu pengalaman yang positif seperti membicarakan tentang situasi nyata, membuat hidup lebih terarah, tujuan masa depan dan merasa mencintai dan dicintai oleh orang lain.

Pada penelitian ini, tujuan hidup dibagi menjadi dua yaitu tujuan hidup akan dunia dan tujuan hidup akan akhirat. Banyak partisipan yang masih berada dalam tahap early adolescent mengakibatkan kecenderungan partisipan belum mampu lepas dari tahap anak-anak. Hal tersebut terlihat dalam setiap jawaban partisipan mengenai tujuan hidup yang masih abstrak.

\section{Harapan}

Harapan merupakan proses dimana
secara cukup intensif dan menetap 
menstimulasi potensi perubahan fisiologi serius (Yusuf dkk 2017 ; Breznitz dalam Appley \& Trumbul 1986).

Pada penelitian ini harapan remaja yang tinggal di eks-lokalisasi dibagi menjadi dua subtema yaitu harapan jangka panjang dan harapan jangka pendek. Harapan jangka panjang artinya harapan yang diperoleh dalam kurun waktu yang tidak dapat ditentukan. Harapan jangka panjang yang ditemukan dalam penelitian ini terkait tentang ibadah dan cita-cita. Harapan jangka pendek berarti sebaliknya yaitu harapan yang diperoleh dalam kurun waktu yang dapat ditentukan. Harapan jangka pendek yang ditemukan dalam penelitian ini terkait tentang harapan untuk orang tua.

Hasil lain menunjukkan bahwa individu yang memiliki hubungan spiritual yang kuat dengan kekuatan yang lebih tinggi karena motivasi intrinsik dan harapan yang cenderung lebih percaya diri dalam kemampuan mereka untuk membuat keputusan karir dan terbuka untuk mengeksplorasi berbagai pilihan karir (Laubach 2004).

\section{Pengalaman Kehidupan}

Pengalaman

kehidupan

merupakan bagian spiritual pengalaman transeden. Transendensi mengacu pada kesadaran atau keterikatan terhadap sesuatu yang melampaui diri, dapat mencakup Tuhan atau kenyataan transenden, namun juga dapat melibatkan aspek kehidupan yang dijiwai dengan kualitas seperti ilahi, seperti imanensi, tanpa batas, dan kekekalan (King and Clardy 2014)

Knoers dan Haditono (1999) dalam Asih (2006) mengatakan bahwa pengalaman merupakan suatu proses pembelajaran dan penambahan perkembangan potensi bertingkah laku baik dari pendidikan formal maupun non formal. Hubungan antara tubuh, pikiran dan spirit menyatu membentuk aspek dalam spiritualitas manusia. Pengalaman dalam kehidupan merupakan bagian dari spiritualitas. Penelitian ini menemukan dua macam pengalaman yang terjadi dalam kehidupan. Pengalaman sebagai sumber pengetahuan dalam melakukan kegiatan mendatang, pengalaman dijadikan pelajaran dalam kehidupan sehari-hari (Haugan 2013).

\section{Cara menghadapi masalah}

Remaja menghadapi masalah dengan berbagai cara. Pada penelitian ini ditemukan dua cara menghadapi masalah yaitu dengan pengalihan dan curhat. Pengalihan perhatian dilakukan remaja untuk melupakan masalah yang terjadi sedangkan kegiatan curhat dilakukan untuk meringankan beban masalah. Aktifitas pengalihan paling sering dilakukan oleh remaja laki-laki, sedangkan pada remaja perempuan sering kali melakukan curhat dengan teman sebaya untuk meringankan masalah yang terjadi.

\section{Gambaran diri}

Gambaran diri merupakan bagian dari konsep diri. Konsep diri merupakan gambaran yang dimiliki seseorang tentang dirinya. Konsep diri dibentuk melalui pengalaman-pengalaman yang diperoleh dari interaksi dengan lingkungan (Agustiani 2009).

Sebuah penelitian menyatakan bahwa masa remaja merupakan periode sensitif untuk pengembangan spiritualitas. Bukti menunjukkan bahwa banyak karakteristik perkembangan normatif remaja mungkin membuat remaja lebih responsif terhadap keinginan spiritual. Karakteristik perkembangan psikologis remaja bersamaan dengan spiritualitas (Good 2008). 
Sejalan dalam penelitian ini ditemukan gambaran diri remaja yang tinggal di eks-lokalisasi yaitu ringan tangan dan optimis. Gambaran diri yang optimis dilakukan agar remaja agar bertahan hidup di lingkungan tersebut. Gambaran diri positif tersebut tidak dipengaruhi oleh keadaan lingkungan yang negatif. Remaja dapat tumbuh dan berkembang sesuai keinginannya.

\section{Gaya Hidup}

Gaya hidup sudah terbentuk pada usia 4-5 tahun, gaya hidup itu tidak hanya ditentukan oleh kemampuan instrinsik (hereditas) dan lingkungan objektif, tetapi dibentuk oleh anak melalui pengamatan dan intepretasinya terhadap keduanya. Gaya hidup tersebut dipandang baik dan buruk berdasarkan role model yang ia ikuti. Kotler (1997) dalam Nadzir (2015) menyatakan bahwa terdapat dua faktor yang mempengaruhi gaya hidup manusia yaitu faktor yang bersal dari dalam individu (internal) dan faktor yang berasal dari luar (eksternal).

\section{KESIMPULAN}

Spiritualitas remaja yang tinggal di sekitar eks-lokalisasi digambarkan melalui bagaimana remaja menjalani kehidupan dengan tujuan dan harapan yang dimiliki. Tujuan hidup remaja dapat dipengaruhi oleh bagaimana interaksi remaja dengan lingkungannya. Dalam hal ini, orang tua memiliki peran besar dalam penentuan terjadi tidaknya interaksi remaja dengan lingkungan eks-lokalisasi.

Faktor perkembangan spiritualitas remaja digambarkan melalui gambaran diri dengan nilai-nilai spiritualitas yang dianut. Remaja mampu mengatasi dan menghadapi berbagai kesulitan, perubahan dan tuntutan dari diri atau lingkungan, memerlukan pandangan atau keyakinan terhadap keseluruhan diri; meliputi konsep, asumsi, dan prinsipprinsip yang dipegang selama hidup sehingga menjadi cermin bagi dirinya dalam memandang dan menilai dirinya sendiri.

\section{DAFTAR PUSTAKA}

Agustiani, H. 2009. Psikologi Perkembangan: Pendekatan Etiologi Kaitannya Dengan Konsep Diri Dan Penyesuaian Diri Pada Remaja. Bandung: Refka Aditama.

Badan Pusat Statistik Republik Indonesia. 2013. Jumlah Angkatan Kerja.

Baihaqi et all. 2010. "Status Identitas Dan Spiritualitas Remaja." artikel penelitian: Status iIentitas dan Spiritualitas Remaja (1980): 15461.

BNN. 2015. BNN Kota Surabaya Advokasi Guru BK SMP SeSurabaya.

BPS. 2014. "Statistik Kriminal." Badan Pusat Statistik (21): 5-6.

Chaplin, JP. 2011. Kamus Lengkap Psikologi. Jakarta: Rajawali Pers.

David ett all. 2000. "The Association between Adolescent Spirituaity and Voluntary Sexual Activity." Journal of Adolescent Health 26(4).

Dik, Ryan Duffy D \& Bryan J. 2009. "Beyond the Self: External Influences in the Career Development Process Beyond the Self: External Influences in the Career Development Process." The Career Development Quarterly Journal 28(1).

Good, Marie. 2008. "Adolescence as a Sensitive Period for Spiritual Development." Wiley Online Library 2(1).

Hacho, Ola. 2014. "Model Pengambilan Keputusan." : 1-15.

Haugan, Gørill. 2013. "Interaction in 
Cognitively Intact Nursing Home Patients." 15(Oecd 1988): 1-18.

Hurlock. 2004. Psikologi Perkembangan Suatu Pendekatan Sepanjang Rentang Kehidupan. Jakrta: Penerbit Erlangga.

Indonesia, Daily. 2012. "BKKBN: Seks Bebas Masalah Utama Remaja."

Kartono. 2006. Patologi Sosial 2 Kenakalan Remaja. Jakarta: PT Raja Grafindo Persada.

Kemenpora. 2009. Penyajian Data Informasi Kementerian Pemuda Dan Olahraga Tahun 2009. Jakarta: Biro Perencanaan Sekretariat Kemetrian Pemuda dan Olahragai.

Kementerian Kesehatan RI. 2016. Profil Kesehatan Indonesia 2015. Jakarta: Kementrian Kesehatan Republik Indonesia.

King, Pamela Ebstyne, and Casey E Clardy. 2014. "Adolescent Spiritual Exemplars : Exploring Spirituality in the Lives of Diverse Youth." Journal of Adolescent Research 29(186-212).

King, Pamela Ebstyne, and Robert W Roeser. 2008. "Religion and Spirituality in Adolescent Development." : 435-78.

Laubach, Marty. 2004. "The Social Effects of Psychism: Spiritual Experience and the Construction of Privatized Religion." Association for the Sociology of Religion 65.

Mufna, Hardjajani, Priyatma. 2004. Hubungan Antara Religiusitas Dan Konsep Diri

Dengan
Kecenderungan Kenakalan Remaja (Studi Korelasi Pada Siswa Kelas Xi Sma Batik 2 Surakarta). Surakarta. Nadzir, Misbahun. 2015. "Psychological Meaning of Money Oengan Gaya Hidup Hedonis Remaja Oi Kota Malang." (1998): 978-79.

Nuqul, Fathul Lubabin. 2015. "Pengaruh Lingkungan Terhadap Perilaku Manusia: Studi Terhadap Perilaku Penonton Bioskop." (Vcd).

Papali, D. E \& Fredlman, R. W. 2009. Human Development Perkembangan Manusia. Jakarta: Salemba Medika.

Pradisukmawati, Dya Lita, and Eko Darminto. 2014. "Hubungan Antara Tingkat Religiusitas Dengan Tingkat Aktivitas Seksual Pada Remaja Akhir." Jurnal ilmiah Psikologi 1(2): 179-85.

Setyaningsih. 2006. "Hubungan Antara Penyesuaian Sosial Dan Kemampuan Menyelesaikan Masalah Dengan Kecenderungan Perilaku Delinkuan Pada Remaja." Jurnal Psikologi Universitas Diponegoro volume 3(1): 29--35.

Sulistiawan, Dedik et al. 2010. "Pendidikan Kesehatan Reproduksi Remaja Melalui Pemberdayaan Pendidik Sebaya Di Kawasan Lokalisasi Dolly Kota Surabaya." : $140-47$.

Yusuf, Ah, Hanik Endang Nihayati, Miranti Florencia Iswari, and Fanni Okviasanti. 2017. Kebutuhan Spiritual. Jakarta: Mitra Wacana Medika. 